of Mount Cassius, and separates it from the first of the valleys of that chain, the Wadi Kondîl; and from the Mediterranean on the west to the Nusairy Mountains on the east. A little to the north of Lattakia the plain juts out into the sea, in the Ras Ibn Hani. The portion of the plain north of Lattakia is low, flat, and separated from that lying east and south-east of the town by a low ridge which divides it from the valley of the Nahr-el-Kebîr. The eastern and south-eastern portion of the plain is traversed by three streams, flowing south-south-west from the Nusairy Mountains, and emptying into the Mediterranean east of the meridian of Lattakia. The first of these is the Nahr-el-Kebîr, the second the Nahr-el-Snowbar, and the third the Nahr-el-Beidha. The surface line of the plain rises gradually from the western limiting ridge of the Nahr-el-Kebîr to the base of the mountains, about five hours (by camel) east of Lattakia. The plain, however, in this portion is so channelled by the deep valleys of the above-mentioned streams and their affluents that it can only be called a plain with reference to an ideal surface tangent to the tops of its hills, or rather ridges, which occupy but a small portion of the total area. The height of the ridges near the centre of the table-land is about 350 feet, and increases gradually, with each successive ridge, until the foot of the mountain is reached. The flanks of these ridges are steep, often at an angle of $45^{\circ}$, and the bottoms of the main streams on the parallel of Lattakia are about 100 feet above the sea.

The soil of this table-land is a tenacions clayey loam, the product of alluvial deposit from the streams which now flow through its valleys. The deposits of marine shells are found at various points in the valleys of all three of the streams flowing through this plain. In my recent visit to some of these localities with Dr. Dodds of Lattakia, my aim was rather to survey the general character of the sites and the nature of the deposits than to make an exhaustive collection of the species, which would require much time and labour.

The nearest locality is in the basin of the Nahr-el-Kebîr, about an hour and a half north-east of Lattakia. Dr. Dodds has visited it, and found it less productive than that which we chose for our search. Our route lay nearly due east from Lattakia to a village called el-Qutrîjeh, three hours away from the town. At a distance of about an hour and a half from Lattakia we came upon a detached mass of conglomerate, the clay of which was barely solidified, containing many of the species of shells and corals which we afterwards found loose in the soil. The mass was about two feet long by a foot broad and six inches thick. It was the only one we found, and the only one found by Dr. Dodds in all his journeys through this plain. Near it were many detached shells, but of two or three species only. The most productive locality is the sides of the ridges east of el-Qutrujeh. What seems most curious is that the shells are almost all found between the levels of 150 and 250 feet (measured by the aneroid). We found few above 250 feet, and those below that level were manifestly carried down by water.

The shells are found loose on the surface of the soil, or projecting from the steep slope of the hillside, associated with recent snail-shells. In a subsequent article I hope to give the names of the species found.

So far as I know, no similar deposit has been found in the alluvium of Syria. In a recent journey through Northern Syria we searched in vain for any traces of marine shells in the western portion of the Lattakia Plain and the valley of the Orontes. I have never seen them in the plains of Akkar, or Esdraelon, or Sharon.

Syrian Protestant College, Beirût, Syria

\section{A Carnivorous Wasp}

A FEW days ago a wasp, which had created some mild excitement by sailing over our luncheon-table, was observed to seize a fly which was on the back of an arm-chair. It settled on the fly, and when I came to look at the butchery-for I cannot call it a fight-the poor fly was minus its head, and I was in time to see one of its wings fluttering down to the ground. The wasp was stretching over its victim and holding him as a spider might do, and on my approach he spread his wings and carried off the body to the other end of the room, presumably to eat it. Both the wasp and the hou efly seemed to be of the common sort which have given so much trouble to the Queen's lieges in this hot weather. I never heard before of a wasp that imitated the habits of a spider. Could you tell me if this is an ordinary thing, or whether it was merely an individual eccentricity of this wasp?

August 16

F. N.

\section{Intelligence of a Frog}

LAST night I rescued a frog from the claws of a cat, and, to my great surprise, it turned, and, after gazing at me for a few seconds, jumped slightly towards me, halling after each leap and looking up into my face. It thus gradually approached, and in about two or three minutes had actually climbed upon one of my feet. Its mute appeal for protection was most remarkable, and could not possibly be misunderstood.

Lawton, August 15

R. R.

\section{Meteor}

LAST night, about I0.20 p.m., I happened to see a meteor worth recording. It moved horizontally, from south to north, across the middle of the western sky) about half way down from the zenith. The sky was cloudless: had that sky not been flooded by the light of a moon that was scarce on the wane, and that extinguished all but very few stars, the meteor would, no doubt, have been a brilliant phenomenon; under the circumstances its splendour was much dimmed. Its course was indicated by a series of small sparkling spangles, which flashed forth beautifully amid the gold-gray glow ; the intermission of its lustre is a noteworthy fact.

Combe Vicarage, near Woodstock, August 8

\section{Podalirius minutus}

IN Prof. Mayer's recent work on the Caprellidæ ("Fauna u. Flora des Golfes Neapal") there is a species figured and described as Podalirius minutus, in which the anterior of the three posterior pairs of thoracic appendages are very minute, contain only two joints, and are attached about midway between the two ends of the segment which bears them. With this marked exception this species agrees very closely on all points with Caprella lobata and C. linearis. My object in drawing attention to it is to ascertain if it has been recorded as a member of the British fauna.

H. C. CHADWICK

\section{$S C A L E S$}

SCALES, as used by the architect and surveyor, may be roughly divided into two classes. In the first we have scales of equal parts, in the second scales of unequal parts, by means of which results may be obtained which otherwise would require more or less calculation. The fundamental idea of a scale of equal parts is that any assigned magnitude may be represented by a line of determinate length, and that thus any relation between magnitudes of the same kind may be indicated by a relation between lines in the same ratio. The simplest form in which they can be used is to represent in an enlarged or diminished size the magnitude of a length, as when, for instance, a mile is represented by an inch. By altering in two rectangular directions the magnitude of an area, we obtain a plan of it in which the scales used may be different for the two directions, as when the crosssection of a stretch of country has one scale for horizontal distances, and a different scale for vertical heights.

By introducing the system of coordinates, and representing, according to selccted scales, the magnitudes of two or three related and dependent quantities, by lengths measured in two or three perpendicular directions, we are able to represent by geometry the connection between those quantities. This is done in innumerable cases in which the plotting of a quantity is effected and is the basis of the methods employed for obtaining continuous records of charging magnitudes. The important subject of graphical arithmetic and statics, curves of velocity, indicator diagrams, curves of bending moment, \&c., as 